\title{
SARS-CoV-2 Variants and Clinical Outcomes: A Systematic Review
}

\author{
Indira R. Mendiola-Pastrana ${ }^{1}{ }^{(0)}$, Eduardo López-Ortiz ${ }^{1}$, José G. Río de la Loza-Zamora ${ }^{1}$, James González ${ }^{2}{ }^{\circledR}$, \\ Anel Gómez-García ${ }^{3}\left[\right.$ and Geovani López-Ortiz ${ }^{1, *}$
}

check for updates

Citation: Mendiola-Pastrana, I.R.; López-Ortiz, E.; Río de la

Loza-Zamora, J.G.; González, J.; Gómez-García, A.; López-Ortiz, G. SARS-CoV-2 Variants and Clinical Outcomes: A Systematic Review. Life 2022, 12, 170. https://doi.org/ $10.3390 /$ life 12020170

Academic Editors: Romina Salpini,

Valentina Svicher and

Mohammad Alkhatib

Received: 19 December 2021

Accepted: 20 January 2022

Published: 25 January 2022

Publisher's Note: MDPI stays neutral with regard to jurisdictional claims in published maps and institutional affiliations.

Copyright: (c) 2022 by the authors. Licensee MDPI, Basel, Switzerland. This article is an open access article distributed under the terms and conditions of the Creative Commons Attribution (CC BY) license (https:// creativecommons.org/licenses/by/ $4.0 /)$.
1 Subdivisión de Medicina Familiar, Facultad de Medicina, Universidad Nacional Autónoma de México, Ciudad de Mexico 04510, Mexico; indira.mendiola@imss.gob.mx (I.R.M.-P.); eduardolptz@gmail.com (E.L.-O.); joseguillermoriodelaloza@hotmail.com (J.G.R.d.1.L.-Z.)

2 Departamento de Biología Celular, Facultad de Ciencias, Universidad Nacional Autónoma de México, Ciudad de Mexico 04510, Mexico; james@ciencias.unam.mx

3 Centro de Investigación Biomédica de Michoacán, Instituto Mexicano del Seguro Social, Morelia 58351, Mexico; anel.gomez.garcia@gmail.com

* Correspondence: geovani.lorz@fmposgrado.unam.mx

\begin{abstract}
Background: From the start of the COVID-19 pandemic, new SARS-CoV-2 variants have emerged that potentially affect transmissibility, severity, and immune evasion in infected individuals. In the present systematic review, the impact of different SARS-CoV-2 variants on clinical outcomes is analyzed. Methods: A systematic review was performed according to the Preferred Reporting Items for Systematic Reviews and Meta-Analyses (PRISMA) 2020. Two databases (PubMed and ScienceDirect) were searched for original articles published from 1 January 2020 to 23 November 2021. The articles that met the selection criteria were appraised according to the Newcastle-Ottawa Quality Assessment Scale. Results: Thirty-three articles were included, involving a total of 253,209 patients and 188,944 partial or complete SARS-CoV-2 sequences. The most reported SARS-CoV-2 variants showed changes in the spike protein, $\mathrm{N}$ protein, RdRp and NSP3. In 28 scenarios, SARS-CoV-2 variants were found to be associated with a mild to severe or even fatal clinical outcome, 15 articles reported such association to be statistically significant. Adjustments in eight of them were made for age, sex and other covariates. Conclusions: SARS-CoV-2 variants can potentially have an impact on clinical outcomes; future studies focused on this topic should consider several covariates that influence the clinical course of the disease.
\end{abstract}

Keywords: SARS-CoV-2 variants; mutations; clinical outcomes; outcome assessment; health care; severity; clinical presentations

\section{Introduction}

Variability in organisms leads to important changes which will have an effect on the course of their evolution [1,2]. In viruses, changes can determine their pathogenicity and virulence $[3,4]$; even single base changes can markedly influence their spread and confer selective advantages [5].

Since the beginning of the COVID-19 pandemic, it has been reported that SARS-CoV-2 has presented multiple changes in its genetic sequence that can potentially increase its infectivity, pathogenicity and antigenic capacity. This could affect the individual's immune response and increase the severity of the clinical outcomes in each of the outbreaks $[6,7]$. One of the first variants to be recognized was D614G in the spike protein [6,8], and as genome sequencing subsequently progressed in different countries, it was reported that different mutations influence the adaptation of the virus to environmental and population contexts, in addition to conferring various phenotypes of clinical interest $[9,10]$.

The clinical course caused by SARS-CoV-2 is associated with country-specific epidemiological and health contexts, age, pre-existing diseases, comorbidities, and host allelic 
variations [11,12]. However, meta-analyses and observational studies have shown that the so-called Variants of Concern increase the risk of disease severity and death, compared to other non-VOC variants, including the original Wuhan or "wild-type" variant $[13,14]$. This opens multiple questions about the interrelationship of the factors that condition the body's responses to SARS-CoV-2 infection and emphasizes the need to study those variables that could impact the outcome of the infection; one question of importance is the interrelationship between variants of the virus and their clinical outcomes, an aspect that, due to the social, biological and methodological heterogeneity of the available evidence, has thus far not been explored in depth [13-15], hence the relevance of developing this systematic review.

\section{Materials and Methods}

The PRISMA 2020 (Preferred Reporting Items for Systematic Reviews and MetaAnalyses) guideline was used [16]. Due to the nature of this review focusing on the association between exposure and clinical outcomes, the PEO (Patient, Exposure of interest and Outcome) approach was used [17], which has been useful in other systematic reviews [18]. The question to be answered: what is the impact of SARS-CoV-2 variants on clinical outcomes in infected persons? A literature search was carried out of articles published from 1 January 2020 to 23 November 2021 in the PubMed and ScienceDirect databases. Advanced algorithm searches were performed using keywords with the use of Boolean operators. Originally, different search algorithms were considered which included the words: SARS-CoV-2 variants, SARS-CoV-2 mutations, Outcome Assessment, Health Care, Clinical Outcome, Clinical Output, Health Outcome, clinical profile, among others, but due to the limited number of articles available with different algorithms $(n=17$ in some cases), the search was circumscribed as follows: ((SARS-CoV-2 Variants) OR (SARSCoV-2 Mutations)) AND (Clinical Outcomes) for PubMed and "SARS-COV-2 Variants" OR "SARS-COV-2 Mutations" AND “Clinical Outcomes" for ScienceDirect.

A literature review was performed, and the available evidence on the topic of interest was condensed selected, compiled, screened, and analyzed independently by two authors (G.L-O. and E.L-O.). Articles focused on SARS-CoV-2 variants and mutations related to clinical outcomes were included. Review articles, essays, opinions, editorials, and case reports were excluded. Studies were analyzed according to changes in SARS-CoV-2 sequences and their clinical outcomes.

In a first approach, G.L-O. and E.L-O., independently analyzed titles and abstracts of 263 articles. After searching and filtering the information, 108 duplicated records were removed, later 107 were excluded after reviewing title and abstract due the articles were not related to the research question. Forty-eight articles were selected for complete reading to determine their relevance for the present review; 15 articles were subsequently removed, 12 because the SARS-CoV-2 variants were not related to clinical outcomes and 3 because the allelic variants were in humans. The controversies were resolved by discussions in which a third author participated (I.R.M-P.); 33 articles met the inclusion criteria.

The Newcastle-Ottawa Quality Assessment Scale checklists adapted for cross-sectional and cohort studies were used to assess the quality of the studies of the selected articles $[19,20]$. This systematic review was registered in OSF (10.17605/OSF.IO/3PM6Q).

Figure 1 presents the procedure used to select relevant articles according to the PRISMA 2020 guideline. 



Figure 1. PRISMA flow diagram for search strategy.

\section{Results}

There were 263 potentially relevant records identified in PubMed and ScienceDirect, 33 met the inclusion criteria. Data from 253,209 patients and 188,944 partial or complete SARS-CoV-2 sequences were analyzed in the referred studies. SARS-CoV-2 variants in the studies were grouped into clades, lineages, and others that were not referred within one of these categories, but by changes at the gene or protein level.

\subsection{SARS-CoV-2 Variants}

Once the articles were selected, the following step was to investigate SARS-CoV-2 mutations related to changes in the phenotype compared to the original virus. These mutations covered different levels of structural organization [21,22], but those that have been studied more are the ones that have an impact at the sequence level on the different viral proteins $[6,23,24]$. 
One of the first variants reported in the COVID-19 pandemic was D614G in the spike protein, which is associated with an increase in viral load, immune escape, possible drug resistance and increased pathogenicity. This amino acid substitution has been maintained in the different current variants. [21,23-26].

It has been pointed out that the region coding for the receptor binding domain (RBD) of the spike protein is prone to accumulate changes in SARS-CoV-2; 13 articles analyzed reported substitutions along this region, among them: N501Y, E484K, N439K, S477N, S399P, and $\mathrm{K} 417 \mathrm{~V}$. It has been proposed that changes in this region could alter binding affinity of SARS-CoV-2 for ACE2 [11,13,15,27-36].

Another reported variant in the spike protein was $\mathrm{P} 681 \mathrm{H}$, which is located near the furin cleavage site and is associated with increased transmissibility and infectivity of SARSCoV-2 [30,33]. The main Variants of Concern present changes in sequences associated to the spike protein, in the RBD and RBM (receptor binding motif) and the furin cleavage site. Some of the most relevant changes in the spike protein are illustrated in Figure 2.

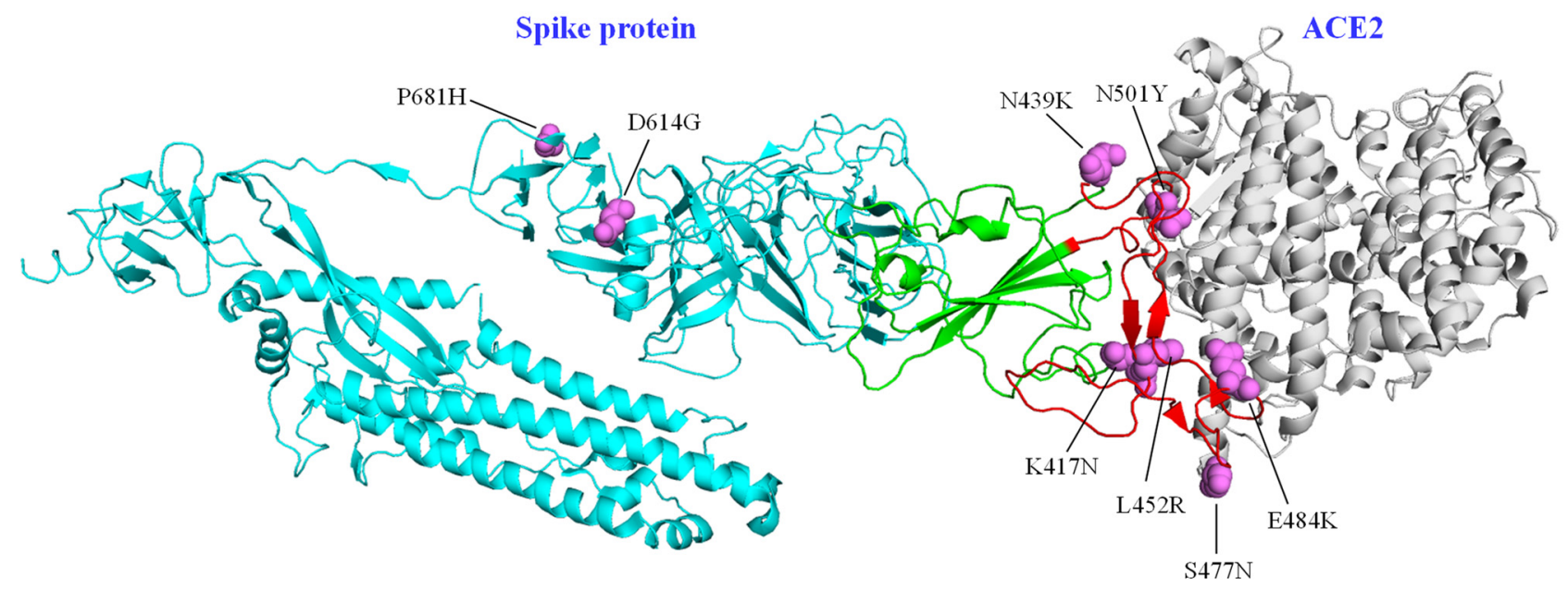

Figure 2. Main changes in spike protein reported in articles analyzed. • Protomer of the spike protein; - RBD; • RBM; • amino acid substitutions, • ACE2 protein, (PDB structure [37,38], PyMOL v.4.6).

The changes in SARS-CoV-2 are distributed in various sites in its sequence-like spike protein, N protein, RNA-dependent RNA polymerase (RdRp), NSP3, NSP4 and other open reading frames (ORFs) (Table 1 ).

Table 1. Changes in SARS-CoV-2 sequences reported in the studies. ${ }^{a}$ Changes in nucleotide sequences.

Changes Location Sources

- D614G, V16F, V367L, K558N, Q675H, A879V, L452R, S939F,

V1176F, K1191N, G1219V, S399P, L54F, N501Y, E484K, S477N,

L5F, V213A, S689R, A570D, T716I, S982A, D1118H, P681H, N439K, V83L, W258R, Q677H, N811I, S640A, V6FS, H66D, D215G, V483A, H655Y, G669S, Q949R, and N1187D.

- m6 A methylation.

- Non-synonymous 21,$575 ; 25,106 ; 23,403 ; 24,099$, and 24,453 . ${ }^{a}$

- Deletion $21,603-21,614 .{ }^{\circ}$

- R203K, I292T, G204R, S202N, M234I, A376T, S194L, P13L, A119S, Q160R, S193I, R195S, P199S, V30L, G212V, and S197L.
Nucleocapsid

phosphoprotein ( $\mathrm{N}$ protein)
$[22,24,28,30,33,35,36,43,44]$ 
Table 1. Cont.

\begin{tabular}{|c|c|c|c|}
\hline & Changes & Location & Sources \\
\hline घ & $\begin{array}{l}\text { L3606F, and C370R. } \\
\text { Synonymous } 19,944 \text {, and } 20,764 .^{a} \\
\text { Insertion } 11,074 .\end{array}$ & ORF1a & {$[22,27,32]$} \\
\hline घ & A138T. & NSP1 & {$[44]$} \\
\hline - & T85I, A205V, V247A, T256I, Q321K and T814I. & NSP2 & {$[30,33,39,44]$} \\
\hline $\mathbf{\square}$ & $\begin{array}{l}\text { F106F, P822L, P679S, T1022I, A1179V, T1198K, F1354C, } \\
\text { P1665L, L916, F924, D1585, N1673, and 8782C. }\end{array}$ & NSP3 & {$[22,24,33,39,41,42,44]$} \\
\hline - & F308Y, S76S, A231V, E3073A, and A323S. & NSP4 & {$[24,33,35,39,41,44]$} \\
\hline - & E3909G. & NSP7 & {$[44]$} \\
\hline - & A21T and T4040I. & NSP8 & {$[33,44]$} \\
\hline $\mathbf{\square}$ & L42F. & NSP9 & {$[33]$} \\
\hline घ & A176S, P314L and V767L. & NSP12 & {$[22,28,41]$} \\
\hline - & P504L, Y541C, T127I, T153I, V169F, M576I, S5398L, and P203L. & NSP13 & {$[33,39,41,44]$} \\
\hline $\mathbf{\square}$ & L7L. & NSP14 & {$[39,41]$} \\
\hline - & H337Y. & NSP15 & [33] \\
\hline - & Y222C. & NSP16 & [33] \\
\hline घ & $\begin{array}{l}\text { G251V, G196V, S253P, Q57H, A54V, A99S, T151I, and D222Y. } \\
\text { Deletion 25,710-25,715. }{ }^{\circ}\end{array}$ & ORF3a & {$[22,24,28,30,33,35,36,39,42-45]$} \\
\hline - & I33T. & ORF6 & {$[24,43]$} \\
\hline - & Deletion $27,508-27,751 .^{a}$ & ORF7b & [43] \\
\hline - & L84S. & ORF8 & {$[23,24,35,36,39,41,45,46]$} \\
\hline - & $\begin{array}{l}\text { A97V, P323L, P232L, P227L, T248I, A656S, H892Y, M906V; } \\
\text { G227A; C865T; Y4424; P4715L, 14408C, and C14408T. } \\
\text { Nucleotic substitution nt14408 }\end{array}$ & $\operatorname{RdRp}$ & $\begin{array}{l}{[22-25,27,30,33,35,36,39,42-} \\
44,47]\end{array}$ \\
\hline घ & G3728S. & 3C-like protease & {$[44]$} \\
\hline
\end{tabular}

\subsection{SARS-CoV-2 Variants and Clinical Outcomes}

SARS-CoV-2 variants can be classified by the statistical distribution related to phylogenetic groups. According to the Global Initiative on Sharing all Influenza Data (GISAID), there are eight clades related to specific genetic markers. Conversely, lineages have been classified according to genetic and epidemiological factors related to outbreaks in different geographic regions [46]. Although there are recommendations about the classification of variants, a significant number of the analyzed studies did not follow them. When analyzing the articles included in this systematic review, there was heterogeneity in classifying and defining variants, nine articles focused on clades, ten on lineages, and eleven on other variants, that were not referred to within these two categories, but by changes at the gene 
or protein level, two studies focused on clades and lineages, and one on clades, lineages and variants (Table 2).

Table 2. SARS-CoV-2 variants and clinical outcomes. ${ }^{\ddagger}$ statistically significant; $\S^{\S}$ non-statistically significant; ${ }^{¥}$ possible associations; $\mathrm{ND}$, not determined.

\begin{tabular}{|c|c|c|c|c|}
\hline \multicolumn{2}{|c|}{ SARS-CoV-2 Variants Analyzed } & \multirow{2}{*}{$\begin{array}{c}\begin{array}{c}\text { Clinical Outcomes } \\
\text { (Main Findings) }\end{array} \\
\begin{array}{c}\text { D614G and clade G are not associated with any } \\
\text { clinical parameter, severity or lethality. }{ }^{\sharp}\end{array}\end{array}$} & \multirow{2}{*}{$\begin{array}{l}\text { Adjustment } \\
\text { Age, sex and } \\
\text { comorbidities }\end{array}$} & \multirow{2}{*}{$\begin{array}{r}\text { Source } \\
{[23]}\end{array}$} \\
\hline - & $\begin{array}{l}\text { Clades } S \text { and } G(\mathrm{GH} \text { and } \\
\text { GR) vs. Wuhan-Hu-1 }\end{array}$ & & & \\
\hline - & $\begin{array}{l}\text { Clade G: D614G (spike } \\
\text { protein). }\end{array}$ & $\begin{array}{c}\text { No association between } \mathrm{D} 614 \mathrm{G} \text { and crude case } \\
\text { fatality rate. } \ddagger\end{array}$ & ND & [25] \\
\hline - & $\begin{array}{l}614 \mathrm{G} \text { vs. } 614 \mathrm{D} \text { (spike } \\
\text { protein) variants. }\end{array}$ & $\begin{array}{c}\text { No evidence of association between the } 614 \mathrm{G} \text { and } \\
614 \mathrm{D} \text { variants and clinical outcomes. } \ddagger\end{array}$ & Age, sex, comorbidities & [26] \\
\hline - & $\begin{array}{l}\text { N439K (spike protein) } \\
\text { variant. }\end{array}$ & No changes in clinical outcomes. $\ddagger$ & ND & {$[31]$} \\
\hline - & $\begin{array}{l}\text { N501Y (spike protein) } \\
\text { variant. }\end{array}$ & No increase in fatality risk. $\ddagger$ & ND & {$[34]$} \\
\hline ש & $\begin{array}{l}\text { Variant with changes in } \\
\text { ORF1a, ORF1b, ORF10, } \\
\text { spike protein, ORF3a, ORF8, } \\
\text { N protein and ORF10. }\end{array}$ & Asymptomatic disease. $\ddagger$ & & \\
\hline - & $\begin{array}{l}\text { Variant with changes in } \\
\text { spike protein, ORF1a, } \\
\text { ORF1b, ORF8 and N protein }\end{array}$ & Mild/Moderate disease. $\ddagger$ & Age and sex & {$[36]$} \\
\hline घ & $\begin{array}{l}\text { Variant with changes in } \\
\text { spike protein, ORF1a, } \\
\text { ORF3a, N protein and RdRp. }\end{array}$ & Severe disease. $\ddagger$ & & \\
\hline - & Clade L, GH, GR and O. & $\begin{array}{l}\text { No significant association in clades with changes } \\
\text { in } S \text { protein with hospitalization or mortality. } \S\end{array}$ & Age and comorbidities & [40] \\
\hline - & $\begin{array}{l}\text { Clade } 1 \text { (V, S, L and Wuhan) } \\
\text { and Clade } 2 \text { (G, GR, and } \\
\text { GH) }\end{array}$ & $\begin{array}{c}\text { Hospitalization and } \\
\text { ICU admission was similar between clades. } \\
\text { Variants containing D614G change were associated } \\
\text { with increased survival in hospitalized patients. } \\
\text { Clade V was statistically related to increased } \\
\text { mortality. }\end{array}$ & $\begin{array}{l}\text { Age, sex and } \\
\text { comorbidities }\end{array}$ & [42] \\
\hline - & $\begin{array}{l}\text { B.1 and B.1.1 lineages, } \\
\text { changes in } 5^{\prime} \text { UTR region, } \\
\text { ORF1a, ORF1b, N protein, } \\
\text { ORF6 and spike protein. }\end{array}$ & No changes in clinical outcomes. $\ddagger$ & ND & [43] \\
\hline - & $\begin{array}{l}\mathrm{A} 1,430 \mathrm{G} \text { o } \mathrm{C} 12,473 \mathrm{~T} \text { and } \\
\text { G227A variants. }\end{array}$ & $\begin{array}{c}\text { G227A increase prolonged viral RNA shedding. } \\
\text { G227A, C7,392T, C15,324T, and C25,626T related } \\
\text { with severe outcomes. } \ddagger\end{array}$ & ND & [47] \\
\hline - & $\begin{array}{l}\text { Clade G: D614G (spike } \\
\text { protein). }\end{array}$ & $\begin{array}{c}\text { Potential increase in severity in infected } \\
\text { individuals. }{ }^{¥}\end{array}$ & ND & {$[6]$} \\
\hline
\end{tabular}


Table 2. Cont.

\begin{tabular}{|c|c|c|c|c|}
\hline \multicolumn{2}{|c|}{ SARS-CoV-2 Variants Analyzed } & \multirow[t]{2}{*}{$\begin{array}{l}\text { Clinical Outcomes } \\
\text { (Main Findings) }\end{array}$} & \multirow{2}{*}{$\begin{array}{c}\text { Adjustment } \\
\text { ND }\end{array}$} & \multirow{2}{*}{$\begin{array}{r}\text { Source } \\
{[15]}\end{array}$} \\
\hline $\mathbf{\square}$ & B.1.1.7 lineage. & & & \\
\hline $\mathbf{\square}$ & ZJ01variant (spike protein). & $\begin{array}{c}\text { m6 A methylation possibly related to } \\
\text { gastrointestinal symptoms. }\end{array}$ & ND & [21] \\
\hline - & Clade GH, GR O and L. & $\begin{array}{l}\text { In clade GH V213A in spike protein was possibly } \\
\text { associated with fatal outcome. } \S\end{array}$ & ND & [33] \\
\hline $\mathbf{\square}$ & $\begin{array}{l}\text { Variants with changes in } \\
\text { D614G (spike protein), } \\
\text { F106F (NSP3), P314L } \\
\text { (NSP12b), 5'UTR, S76S } \\
\text { (NSP4), L84S (ORF8), L7L } \\
\text { (NSP14), Y541C and P504L } \\
\text { (NSP13). }\end{array}$ & $\begin{array}{l}\text { Y541C and P504L variants associated with possible } \\
\text { infection and mortality rates. } \ddagger\end{array}$ & ND & [41] \\
\hline $\mathbf{\square}$ & $\begin{array}{l}\text { Variants with multiple } \\
\text { changes in NSP4, NSP6, } \\
\text { NSP7, NSP8, NSP13, spike } \\
\text { protein, RdpRp, N protein } \\
\text { and 3C-like protease. }\end{array}$ & $\begin{array}{l}\text { L3606-Nsp6 deletion, S5398L and E3909G-Nsp7 } \\
\text { were linked to a higher prevalence of cough and } \\
\text { conjunctival congestion, increased risk of fever } \\
\text { duration and progression and shorter duration of } \\
\text { symptoms, respectively. }\end{array}$ & $\begin{array}{l}\text { Age, sex and } \\
\text { comorbidities }\end{array}$ & {$[44]$} \\
\hline
\end{tabular}

- Variant with changes in L54F, D614G and V1176F (spike protein), A97V and P323L (RdRp), Q57H and G251V (ORF3a), P13L, Hospitalization and severe disease. $\ddagger$ S194L, R203K, G204R and I292T (N), I33T (ORF6), S1197R and T1198K (NSP3).

- Variant with changes in L84S (ORF8), G196V

(ORF3a), L37F (NSP6),

Mild disease. $\ddagger$ F308Y (NSP4) and S197L (N protein)

- Variant with changes in L71F (NSP7) and S253P (ORF3A)

Fatal outcomes. $\ddagger$

- Clade $1(\mathrm{GH} / 20 \mathrm{C}, \mathrm{G} / 20 \mathrm{~A}$ and $\mathrm{G} / 20 \mathrm{~B}$ ) vs. Clade 2 (S/19B and L/19A).
Trend toward higher rates of hospitalization in clade $2 . \S$

Viral clade contributes minimally to clinical outcome. ${ }^{\sharp}$

- Variant with changes in L84S (ORF8) and G251V (ORF3a).

Clades $\mathrm{S}$ and $\mathrm{O}$ were associated with mild and attenuated disease, respectively. $\ddagger$

Clades L/V were associated with higher concentrations of cytokines, chemokines and growth factors related to lung injury and regeneration, severe outcome. $\ddagger$ 
Table 2. Cont.

\begin{tabular}{|c|c|c|c|c|}
\hline \multicolumn{2}{|c|}{ SARS-CoV-2 Variants Analyzed } & $\begin{array}{l}\text { Clinical Outcomes } \\
\text { (Main Findings) }\end{array}$ & Adjustment & Source \\
\hline - & Clade G (GH and GR) & $\begin{array}{l}\text { Associated with lower risk of severe disease and } \\
\text { transmissibility. }\end{array}$ & & \\
\hline $\mathbf{\square}$ & M1 variant vs. Clade $20 \mathrm{AS}$ & $\begin{array}{l}\text { Lower rates of severe disease and hospitalization } \\
\text { in clade 20AS. }\end{array}$ & \multirow{5}{*}{$\begin{array}{l}\text { Age, sex and } \\
\text { comorbidities }\end{array}$} & \multirow{5}{*}{ [48] } \\
\hline - & $\begin{array}{l}\text { B.1.160 lineage vs. M1 } \\
\text { variant and Clade 20AS }\end{array}$ & Tendency to mild disease in MV4. $\ddagger$ & & \\
\hline - & $\begin{array}{l}\text { B.1.160 lineage vs. Clade } \\
\text { 20AS. }\end{array}$ & Lower rates of mild disease in MV4. $\ddagger$ & & \\
\hline $\mathbf{\square}$ & $\begin{array}{l}\text { B.1.160 lineage vs. M1 } \\
\text { variant. }\end{array}$ & Higher rates of hospitalization in MV4. $\ddagger$ & & \\
\hline $\mathbf{\square}$ & $\begin{array}{l}\text { N501Y variant vs. Clade } \\
20 A S \text { and B.1.160 lineage. }\end{array}$ & Lower rates of hospitalization in N501Y. $\ddagger$ & & \\
\hline - & $\begin{array}{l}\text { B.1.1.7 lineage vs. } \\
\text { non-B.1.1.7. }\end{array}$ & Severe disease in women associated with B.1.1.7. $\ddagger$ & $\begin{array}{l}\text { Age, sex, ethnicity and } \\
\text { number of comorbidities }\end{array}$ & [11] \\
\hline $\mathbf{\square}$ & $\begin{array}{l}\text { B.1 and B.2, lineages. } \\
\text { Multiple changes in ORF1a, } \\
\text { spike protein, ORF3a, } \\
\text { ORF1b, N protein, ORF14, } \\
\text { OFR8 and presence of } \\
\text { indels. }\end{array}$ & $\begin{array}{l}\text { Higher number of changes in RNA and protein } \\
\text { sequences in patients were associated with severe } \\
\text { symptoms compared to mild, especially in elderly. } \\
\ddagger\end{array}$ & ND & [27] \\
\hline $\mathbf{\square}$ & $\begin{array}{l}\text { B.1.160 lineage vs. Clade } \\
\text { 20A. }\end{array}$ & $\begin{array}{l}\text { Trend toward hypoxemia in MV4 due to short } \\
\text { protective immunity or a lack of cross-immunity. }\end{array}$ & ND & [28] \\
\hline - & $\begin{array}{l}\text { Clade 20A, Clade 20B, } \\
\text { Clade 20C, B.1.177, B.1.160, } \\
\text { B.1.1.7, B.1.351, P.1 and A.27 } \\
\text { lineages. }\end{array}$ & $\begin{array}{l}\text { B.1.177 and B.1.160 variants were associated with } \\
\text { more severe outcomes, including mortality } \\
\text { compared with the other variants and clades. }\end{array}$ & ND & [29] \\
\hline - & $\begin{array}{l}\text { V1176F, S477N and DG14G } \\
\text { (spike protein) and S194L } \\
\text { (N protein) variants vs. } \\
\text { Wuhan strain }\end{array}$ & $\begin{array}{c}\text { Severe disease was statistically associated with } \\
\text { changes in spike protein. } \ddagger\end{array}$ & ND & {$[35]$} \\
\hline - & $\begin{array}{l}\text { B.1.1.7, B.1.351 lineages and } \\
\text { non-VOC lineages. }\end{array}$ & $\begin{array}{l}\text { B.1.1.7 and B.1.351 were associatedwith increased } \\
\text { risk of hospitalization and intensive care unit } \\
\text { (ICU) admission. } \ddagger\end{array}$ & $\begin{array}{l}\text { Age, sex and number of } \\
\text { comorbidities }\end{array}$ & [49] \\
\hline - & $\begin{array}{l}\text { B.1.1.7, B.1.351, B.1.617.2 } \\
\text { lineages and non -VOC } \\
\text { lineages. }\end{array}$ & $\begin{array}{l}\text { B.1.617.2 was associated with higher odds or } \\
\text { oxygen requirement, ICU admission or death. }\end{array}$ & $\begin{array}{l}\text { Age, sex, comorbidities } \\
\text { and vaccination. }\end{array}$ & {$[50]$} \\
\hline - & B.1.617.2 lineage. & $\begin{array}{l}\text { No differences in hospitalization rates, ICU } \\
\text { admission and mortality. }\end{array}$ & ND & [51] \\
\hline - & $\begin{array}{l}\text { B.1.1.7 lineage vs. } \\
\text { non-B.1.1.7. }\end{array}$ & $\begin{array}{l}\text { Higher risk of ICU admission and mortality were } \\
\text { associated with B.1.1.7. }{ }^{\ddagger}\end{array}$ & $\begin{array}{l}\text { Age, sex, ethnicity, BMI } \\
\text { and severe comorbidities }\end{array}$ & [13] \\
\hline
\end{tabular}


Table 2. Cont.

\begin{tabular}{|c|c|c|c|c|}
\hline \multicolumn{2}{|c|}{ SARS-CoV-2 Variants Analyzed } & $\begin{array}{l}\text { Clinical Outcomes } \\
\text { (Main Findings) }\end{array}$ & Adjustment & Source \\
\hline घ & $\begin{array}{l}\text { Clades 19A, 20A and 20B: } \\
\text { multiple changes located in } \\
\text { ORF1b, spike protein, } \\
\text { ORF3a, ORF1a, N protein } \\
\text { and NSP3. }\end{array}$ & $\begin{array}{c}\text { Changes in A26194T, C25611A, C28854T and } \\
\text { TG11082T were associated with higher rates of } \\
\text { severe disease and mortality. }\end{array}$ & ND & [22] \\
\hline - & $\begin{array}{l}\text { B.1.2, B.1.1.7, B.1.243, } \\
\text { B.1.596 and B.1.526.1 } \\
\text { lineages. }\end{array}$ & $\begin{array}{c}\text { B.1.243 was associated with severe or fatal } \\
\text { outcome. } \ddagger\end{array}$ & ND & [30] \\
\hline $\mathbf{\square}$ & $\begin{array}{l}\text { B.1.616 vs. B.1.1.7, B.1.351 } \\
\text { and P.1 lineages. }\end{array}$ & $\begin{array}{l}\text { Severe disease and lethality were associated with } \\
\text { B.1.616. } \ddagger\end{array}$ & $\begin{array}{l}\text { Age, comorbidities and } \\
\text { healthcare-related } \\
\text { COVID-19 }\end{array}$ & {$[32]$} \\
\hline
\end{tabular}

When analyzing SARS-CoV-2 variants with their outcomes, ten articles reported that there was no relationship $[23,25,26,31,34,36,40,42,43,47]$; in six, there were possible associations between variants and clinical outcomes (from moderate to severe) $[6,15,21,33,41,44]$, while in nine scenarios, mild clinical outcomes were reported $[24,36,39,45,46,48]$, in fourteen severe outcomes [11,24,27-29,35,36,39,46,48-51], and in five fatal outcomes [13,22,24,30,32] (different outcomes were reported in more than one study). A statistically significant association was reported (from mild to severe/fatal) between variants and clinical outcomes in fifteen articles $[11,13,22,24,27,28,30,32,35,36,46,48-51]$. In eight of them, adjustments for age, sex, or other covariates were made [11,13,32,36,46,48-50] (Table 2).

Prior to the reporting of Variants of Interest (VOI) and Variants of Concern (VOC), changes in the SARS-CoV-2 sequence that could have an impact on clinical outcomes had been determined [6]. The D614G variant in the spike protein was initially considered to be related to a higher rate of hospitalizations and moderate to severe clinical outcomes $[6,23]$; however, analyses in different cohorts showed no relationship with disease severity; this change increases the adaptability of the virus in human populations, without necessarily causing more severe disease $[25,43]$. The same scenario was visualized for the N439K variant in the spike protein, which was also not found to have a direct effect on clinical outcomes, compared to the original virus. However, it was reported that this substitution had emerged in different clades independently and that it increased affinity for ACE2 and resistance against various neutralizing monoclonal antibodies [31].

A study determined that polygenic mutations in SARS-CoV-2 had different outcomes. For mild disease, the following amino acid changes were detected: L84S, G196V in ORF8 and ORF3a, respectively, as well as L37F substitutions in NSP6, F308Y in NSP4 and S197L in the $\mathrm{N}$ protein. When analyzing sequences of hospitalized patients, 15 changes distributed in seven genes were found: three in the spike protein, two in RdRp, two in ORF3a, five in N protein, one in ORF6 and two in NSP3; while in fatal outcomes, L71F changes were found in NSP7 and S253P in ORF3a [24].

In a study where associations between different mutations and clinical outcomes were analyzed, Zekri et al. [44] found in a sample of 50 patients that the V6 deletion in the spike protein was associated with an increased risk and duration of fever and nasal congestion, while the L3606-Nsp6 deletion was associated with an increased presence of cough and conjunctival congestion.

When variants with changes in P504L, as well as Y541C in NSP13 were analyzed, an association was found between these with infection and mortality rates, without correlation with other studies [41]. Likewise, the N501Y variant in the spike protein was found to have an increase, without statistical significance, of $18 \%$ in terms of risk of fatal outcome [34]. 
In silico studies have allowed for a proposal that there are mutation signatures responsible for promoting mild and severe outcomes, in which 20 mutations could be used to separate both groups. These are distributed in the gene encoding the spike protein, as well as in other viral proteins and in untranslated regions (UTRs). [35] This has allowed for development of models to predict the degree of severity by adjusting the age of patients and analyzing their viral sequences (https: / / covidoutcome.com/, accessible from 27 December 2021).

It has been proposed that mutations in ORF1a, ORF1b and in genes encoding $\mathrm{N}$ protein were related to a high prevalence of asymptomatic scenarios. However, when D614G, Q57H (ORF3a) and S194L (N protein) changes were present, they were associated with mild and severe outcomes. Likewise, a single nucleotide change (nt14408) in RdRp was associated with severe cases of the disease [36].

Regarding prolonged viral RNA shedding, which can be up to 100 days in patients with severe disease, one study reported that viral shedding time decreases when A1,430G or $\mathrm{C} 12,473 \mathrm{~T}$ mutations are present and increases when $\mathrm{G} 227 \mathrm{~A}$ is present $(p<0.05)$. Likewise, mutations in G227A, C7,392T, C15,324T, and C25,626T were mostly represented in severe disease cases [47].

The analysis of SARS-CoV-2 variants and their impact on clinical outcomes must be seen from an integral perspective; thus, the different levels of structural organization that make up the variants must be evaluated. In this context, it was determined that three structural changes at the RNA and protein levels, specifically A26194T (T268S) and C25611A (synonymous mutation) in the ORF3a region and C28854T (S194L) in the $\mathrm{N}$ protein were associated with an increase in severe cases and fatal outcomes $(p<0.05)$ [22]

Methylation at the m6 A loci of the spike protein has been identified in patients debuting with gastrointestinal symptoms, which could provide underlying mechanisms for its change in virulence and transmission capacity during outbreaks and affect the outcome for serious and severe disease [21].

\subsection{Rise and Spread of Variants of Concern}

As more functional changes in the SARS-CoV-2 sequence were reported, some variants began to be identified by different surveillance systems due to the speed with which their presence was increasing. This has been a cause for concern because it in unknown what effect these changes may have on clinical outcomes, diagnoses and vaccine efficacy $[23,29]$. The differences of some varieties of the virus from the second half of 2020, their rapid spread, as well as the lack of a clear notation for their classification make it necessary to define the VOCs $[13,15,29]$.

Chronologically, the reported VOCs in the studies analyzed were:

Beta (B.1.351): it was first documented in May 2020, in addition to the D614G substitution, this variant presents other changes such as E484K and N501Y that confer the capacity of immune escape by effect of previous infection or vaccination; the increase in its transmission has been estimated at around 50\% compared to the Wuhan variant [30].

Alpha (B.1.1.7): identified in September 2020, presents a 70\% increase in transmissibility, consequence of key changes, specifically in the RBM (N501Y) and near the furin cleavage site $(\mathrm{P} 681 \mathrm{H})$, which could increase the affinity for ACE2 and have an impact on infection and transmission, respectively; [30] this could have contributed to the rapid dispersion and dominance of this variant in the world before the arrival of the Delta variant (B.1.617.2). [11,50,51].

Delta: identified in October 2020, it has become the most common variant globally, its main changes are D614G, E484Q and L452R, it has been reported that this variant has biological and clinical implications such as increased risk of hospitalization, longer duration of virus release by infected persons, low Ct values in PCR, greater affinity to the ACE2 receptor, mechanisms of escape to the effect of antibodies and transmissibility increased by $50 \%[50,51]$. 
Gamma (P.1): first documented in November 2020, highlighting the presence of three changes that confer affinity for the ACE2 receptor, these are K417T, E484K and N501Y which contribute to its increased transmissibility estimated at $40 \%$ in relation to the first variants [30].

When independently analyzing the clinical outcomes associated with VOC, it was identified that the Alpha and Delta variants affect individuals with similar demographic and comorbidity characteristics, while patients infected with the Gamma variant are older people, mainly between 45 and 64 years old, with a higher probability of presenting cough and anosmia, compared to the other variants $[29,30]$.

One of the largest studies conducted to date, focused on determining fatal outcomes and admission to intensive care unit (ICU), showed that people infected with the Alpha variant had a higher risk of admission to ICU and 28-day mortality compared to those infected with other unrelated lineages [13]. Likewise, Veneti et al., [49] analyzed 23,169 cases of infected individuals with the Alpha and Beta variants as well as other non-VOCs and determined that these two VOCs were associated with an increased risk of hospitalization and ICU admission.

The analysis by sex has documented significant differences in clinical outcomes associated with variants. In this regard, a study reported that women infected with the B.1.1.7 lineage develop a more severe disease compared to men, as well as women infected with other lineages, these outcomes are associated with admission to ICU, as well as a slight risk of mortality [11].

One study concluded that the Delta variant, after adjusting age and sex, was associated with increased oxygen requirement, admission to ICU, and death when compared with Alpha and Beta. It was also reported that this variant was associated with increased viral loading, as well as prolonged viral shedding [50]. In contrast, another study noted that the presence of this variant in different parts of the United States of America did not result in increased hospitalizations, ICU admission or death in adults. Partly, impact of this variant on transmission rates and fatal outcomes was associated with people who had not yet been vaccinated, including adults younger than 50 years of age [51].

\subsection{Other Variants Related with Clinical Outcomes}

The dynamics of the SARS-CoV-2 variants analyzed throughout the pandemic has been complex. In France, after the first outbreak there were new variants that had an epidemiological impact; in the comparative study by Fournier et al. [28] it was determined that the Marseille-4 variant had 13 changes, one of which (S477N) was associated with hypoxemia $(p<0.05)$. This variant could be associated with changes in the affinity for ACE2 and decrease the sensitivity of the virus to neutralizing antibodies. In this same context, a cohort study conducted in France determined that lineages B.1.177 and B.1.160, Marseille-2 and Marseille-4, respectively, during the second phase of the pandemic, were associated with more severe clinical outcomes and consequently higher mortality and hospitalization rates [29], however in this study the association between variants and disease severity was not clear.

Conversely, the B.1.243 lineage was found to be significantly associated with a high degree of disease severity and fatal outcomes. This lineage shows several substitutions in NSP12:P323L, N:S194L as well as D614G and P681H changes in the spike protein [30].

The B.1.616 lineage whose differences from the original SARS-CoV-2 are centered on nine changes and one deletion in the spike protein (H66D, G142V, Y144del, D215G, V483A, D614G, H655Y, G669S, Q949R, N1187D), as well as changes in other regions, was associated with a high 28-day fatality rate when compared to VOC and other unknown lineages $(p<0.05)$ [32].

Conversely, when analyzing the degree of disease severity with SARS-CoV-2 variants, Al Khatib et al. [27] identified changes in specific regions of the B.1 and B.2 lineages associated with severe symptoms; patients who developed worse clinical scenarios had greater variability in the SARS-CoV-2 analyzed sequences ( $p$ value 0.001 ). 
When different clades were analyzed with respect to their clinical outcomes, it was determined that the L/V clades (variant of the ORF3a coding protein NS3-G251) were associated with more severe outcomes as they had more pronounced systemic inflammation with higher concentrations of proinflammatory cytokines, chemokines and growth factors compared to the G, S and O clades [46]. Conversely, when outcomes were analyzed with respect to infection by the $\mathrm{G}$ and $\mathrm{S} / \mathrm{L}$ clades, it was observed that, regardless of clade, the results were similar in terms of rate of hospitalizations and death [39]. One study reported that clade $\mathrm{V}$ was statistically related to increased mortality in uni- and multivariate analyses compared to other variants [42].

It has been reported that the M1V variant has lower rates of dyspnea, rhinitis and hospitalizations, which has been related to its infection in younger age groups, while the M4V variant infects mainly older adults and has a higher probability of producing fever, lower frequency of cough, rhinitis and olfactory and gustatory disorders, as well as a higher rate of hospitalization associated with hypoxemia. It has also been noted that the $\mathrm{M} 4 \mathrm{~V}$ variant confers some immunological escape and has been the responsible for cases of reinfection $[28,48]$.

\subsection{Critical Appraisal of the Studies}

There was a heterogeneous presentation in the articles analyzed in terms of study design, SARS-CoV-2 variants, and specific description of clinical outcomes. The selected studies were appraised using the Newcastle-Ottawa Quality Assessment Scale checklists adapted for cross-sectional and cohort studies $[19,20]$. Regarding cross-sectional and cohort studies, four $(12.12 \%)$ were scored as satisfactory, fifteen $(45.46 \%)$ were scored as good and one $(3.03 \%)$ was scored as very good. The rest of the studies included ten $(30.30 \%)$ experimental and one (3.03\%) mathematical modeling analysis, and two (6.06\%) short communications were restricted to the description of their limitations (Table 3).

Table 3. Critical appraisal of selected studies. § The Newcastle-Ottawa Quality Assessment Scale checklists adapted for cross-sectional and cohort studies. ND, not determined. * Asterisks correspond to ratings assigned for each item according to The Newcastle-Ottawa Quality Assessment Scale.

\begin{tabular}{|c|c|c|c|c|c|c|c|}
\hline \multicolumn{8}{|c|}{ Critical Appraisal of Selected Studies } \\
\hline \multirow{2}{*}{ Source } & \multirow{2}{*}{ Design Study } & \multirow{2}{*}{ Sample Size } & \multirow{2}{*}{ Limitations } & \multicolumn{4}{|c|}{ Appraisal ${ }^{\S}$} \\
\hline & & & & Selection & Comparability & Outcome & Score \\
\hline$[21]$ & Cross-sectional & 651 patients & $\begin{array}{l}\text { Lack of predictive model for disease } \\
\text { progression }\end{array}$ & $* * * *$ & * & $* *$ & 7 \\
\hline$[24]$ & Cross-sectional & 4556 patients & $\begin{array}{l}\text { Sampling bias, database with general } \\
\text { information and cofounding factors }\end{array}$ & $* * *$ & $* *$ & $* *$ & 7 \\
\hline$[39]$ & Cross-sectional & 190 patients & $\begin{array}{l}\text { Cofounders and data limited to } \\
\text { hospitalization and death and not } \\
\text { generalizable to others geographical } \\
\text { regions or health systems }\end{array}$ & $* * * *$ & $* *$ & $* *$ & 8 \\
\hline$[40]$ & Cross-sectional & 51 patients & $\begin{array}{l}\text { Small sample size and analysis } \\
\text { limited to some mutations and } \\
\text { prognostic factors }\end{array}$ & $* * *$ & $* *$ & $* * *$ & 8 \\
\hline [42] & Cross-sectional & 302 patients & Underrepresented clades & $* * * *$ & ** & $* * *$ & 9 \\
\hline$[33]$ & Cross-sectional & 17 patients & $\begin{array}{c}\text { Small sample size and } \\
\text { underrepresented clusters }\end{array}$ & $* * *$ & * & $* *$ & 6 \\
\hline$[15]$ & Cross-sectional & 1479 patients & $\begin{array}{l}\text { Retrospective incomplete data and } \\
\text { small sample size }\end{array}$ & $* * *$ & * & $* *$ & 6 \\
\hline$[51]$ & Cross-sectional & 7615 patients & $\begin{array}{l}\text { Undercounted hospitalizations and } \\
\text { population groups and small sample } \\
\text { size }\end{array}$ & $* * *$ & ** & $* *$ & 7 \\
\hline
\end{tabular}


Table 3. Cont.

\begin{tabular}{|c|c|c|c|c|c|c|c|}
\hline \multicolumn{8}{|c|}{ Critical Appraisal of Selected Studies } \\
\hline \multirow{2}{*}{ Source } & \multirow{2}{*}{ Design Study } & \multirow{2}{*}{ Sample Size } & \multirow{2}{*}{ Limitations } & \multicolumn{4}{|c|}{ Appraisal $\S$} \\
\hline & & & & Selection & Comparability & Outcome & Score \\
\hline [27] & Cross-sectional & 46 patients & $\begin{array}{l}\text { Small sample size restricted to some } \\
\text { age groups and levels of disease } \\
\text { severity }\end{array}$ & $* * *$ & $*$ & ** & 6 \\
\hline [43] & Cross-sectional & 71 participants & $\begin{array}{l}\text { Heterogeneity in age and disease } \\
\text { severity }\end{array}$ & $* * *$ & $* *$ & $* *$ & 7 \\
\hline [44] & Cross-sectional & 50 patients & $\begin{array}{l}\text { Underestimated geographical and } \\
\text { density viral distribution }\end{array}$ & $* * *$ & $* *$ & $* *$ & 7 \\
\hline [46] & Cohort & 319 patients & Selection and information bias & $* * *$ & $* *$ & $* * *$ & 8 \\
\hline [48] & Cohort & 740 patients & $\begin{array}{l}\text { Missing data and convenience } \\
\text { sampling }\end{array}$ & $* * *$ & $* *$ & $* * *$ & 8 \\
\hline [29] & Cohort & 1760 patients & Selection bias & $* * *$ & $* *$ & $* * *$ & 8 \\
\hline [49] & Cohort & 28,301 patients & Selection and information bias & $* * *$ & ** & $* *$ & 7 \\
\hline [50] & Cohort & 1675 patients & Small sample size and selection bias & $* * *$ & $* *$ & $* *$ & 7 \\
\hline [47] & Cohort & 43 patients & $\begin{array}{c}\text { Small sample size, lack of paraclinical } \\
\text { information in severe/critical cases } \\
\text { and measurement bias }\end{array}$ & $* * * *$ & & $* *$ & 6 \\
\hline [13] & Cohort & $\begin{array}{c}202,692 \\
\text { patients }\end{array}$ & $\begin{array}{l}\text { Selection bias, cofounders and } \\
\text { restricted analysis }\end{array}$ & $* * * *$ & $* *$ & $* *$ & 8 \\
\hline [11] & Cohort & 2341 patients & $\begin{array}{l}\text { Sample restricted to hospitalized } \\
\text { patients and not generalizable to the } \\
\text { population and lack of information } \\
\text { about patients' vaccination status }\end{array}$ & $* * * *$ & ** & $* *$ & 8 \\
\hline [32] & Cohort & 114 patients & $\begin{array}{l}\text { Small sample size, retrospective } \\
\text { design and selection of controls }\end{array}$ & $* * * *$ & ** & * & 7 \\
\hline [22] & Experimental & $\begin{array}{c}196 \\
\text { participants }\end{array}$ & $\begin{array}{l}\text { Limited data due to the need of an } \\
\text { integrative analysis in which clinical } \\
\text { and genetic components of the disease } \\
\text { are co-analyzed }\end{array}$ & & ND & & \\
\hline [36] & Experimental & $\begin{array}{l}1329 \\
\text { SARS-CoV-2 } \\
\text { genome } \\
\text { sequences }\end{array}$ & $\begin{array}{l}\text { Lack of correlation in broader clinical } \\
\text { scenarios }\end{array}$ & & ND & & \\
\hline [25] & Experimental & $\begin{array}{l}2803 \\
\text { SARS-CoV-2 } \\
\text { genome } \\
\text { sequences }\end{array}$ & $\begin{array}{c}\text { Lack of clinical metadata, sampling } \\
\text { bias and heterogeneity in population } \\
\text { demographics, testing, definitions and } \\
\text { measurements }\end{array}$ & & ND & & \\
\hline [35] & Experimental & $\begin{array}{l}9781 \\
\text { SARS-CoV-2 } \\
\text { genomes } \\
\text { sequences }\end{array}$ & $\begin{array}{l}\text { Limited data due to statistical } \\
\text { associations that should be confirmed } \\
\text { by other studies }\end{array}$ & & ND & & \\
\hline [31] & Experimental & 442 samples & Limitation in data collection & & ND & & \\
\hline [23] & Experimental & $\begin{array}{l}44 \text { SARS-CoV-2 } \\
\text { genome } \\
\text { sequences }\end{array}$ & $\begin{array}{l}\text { Limited phylogenetic, } \\
\text { phylogeographic and clinical } \\
\text { correlation analyses }\end{array}$ & & ND & & \\
\hline [28] & Experimental & $\begin{array}{l}1038 \\
\text { SARS-CoV-2 } \\
\text { genome } \\
\text { sequences }\end{array}$ & Limited to a single geographic area & & ND & & \\
\hline
\end{tabular}


Table 3. Cont.

\begin{tabular}{|c|c|c|c|c|c|c|c|}
\hline \multicolumn{8}{|c|}{ Critical Appraisal of Selected Studies } \\
\hline \multirow{2}{*}{ Source } & \multirow{2}{*}{ Design Study } & \multirow{2}{*}{ Sample Size } & \multirow{2}{*}{ Limitations } & \multicolumn{4}{|c|}{ Appraisal $\S$} \\
\hline & & & & Selection & Comparability & Outcome & Score \\
\hline [30] & Experimental & $\begin{array}{c}1600 \\
\text { SARS-CoV-2 } \\
\text { complete or } \\
\text { near-complete } \\
\text { genomes }\end{array}$ & $\begin{array}{l}\text { Small sample of severe cases } \\
\text { restricting adjustment and analysis of } \\
\text { good quality genomes }\end{array}$ & & ND & & \\
\hline [26] & Experimental & $\begin{array}{l}3940 \text { genomes } \\
\text { sequences }\end{array}$ & Sampling bias & & ND & & \\
\hline [41] & Experimental & $\begin{array}{l}1962 \text { genome } \\
\text { sequences }\end{array}$ & Lack of analysis of covariates & & ND & & \\
\hline [34] & Experimental & $\begin{array}{l}149,789 \\
\text { SARS-CoV-2 } \\
\text { genomes } \\
\text { sequences }\end{array}$ & $\begin{array}{c}\text { Intrinsic biological mechanisms, } \\
\text { co-mutations and lack of individual } \\
\text { patients' information }\end{array}$ & & ND & & \\
\hline [6] & $\begin{array}{l}\text { Short commu- } \\
\text { nication }\end{array}$ & $\begin{array}{l}\text { 4246SARS- } \\
\text { CoV-2genome } \\
\text { sequences }\end{array}$ & $\begin{array}{l}\text { Limited data due to absence of } \\
\text { experimental studies }\end{array}$ & & ND & & \\
\hline [45] & $\begin{array}{l}\text { Short commu- } \\
\text { nication }\end{array}$ & $\begin{array}{l}11970 \\
\text { SARS-CoV-2 } \\
\text { genome } \\
\text { sequences }\end{array}$ & Limited data to establish associations & & ND & & \\
\hline
\end{tabular}

\section{Discussion}

Different variants of SARS-CoV-2 have emerged from geographic regions whose epidemiological conditions allowed for the stabilization of certain genetic combinations that had an impact on their fitness. It has been proposed that the origin of SARS-CoV-2 variants are hosts with long periods of infections, as people with cancer or immunocompromised condition, as well as uncontrolled circulation in countries with poor health infrastructure, which when added to selection pressures, has favored the adaptation and dominance of new lineages [7,30,40,43,50,52].

Studies in SARS-CoV-2 have focused on the spike protein (Table 1 and Figure 2), changes in its sequence have been associated with increased affinity for ACE2, immune escape and increased infectivity and transmissibility [7]. In evolutionary terms, this suggests that there are specific regions that are susceptible to accumulate mutations under positive selection, regardless of lineages of origin. However, the sites that may have an impact on severity, as well as on the emergence and evolution of new variants, are not circumscribed to a single protein (Table 1). It has been pointed out that, in parallel to local and global epidemiological contexts, the D614G substitution in the spike protein, as well as the R203K and G204R in the N protein, have been important in increasing fitness for SARS-CoV-2 [53].

SARS-CoV-2 variants are characterized by mutations in their genome, with respect to the original strain, understanding at molecular level the impact of these variants will improve our understanding of their mechanisms of infection $[54,55]$. In this scenario, D614G substitution prevents the interaction of a hydrogen bond with the T859 residue of an adjacent protomer of the spike protein trimer; this leads to a conformational change in the RBD to an "up" conformation, which promotes greater binding to ACE2; it has been mentioned that this promotes greater infectivity of the virion, which has been verified in experimental studies [56-58]. Regarding the P681H substitution, this is part of a proteolytic cleavage site for furin and furin-like proteases; it has been pointed out that, in parallel to the cleavage of arginine-rich multi-basic motifs, there may be a preference for other basic residues such as histidine, which could favor the cleavage of S1/S2 in the spike protein and impact the infectious capacity of SARS-CoV-2. [59]. Conversely, it has been reported in an in silico study that the histidine residue shortens the distance by $2 \AA$ with respect to proline, which could promote the binding of spike protein with Neuropilin 1, this protein 
is a co-receptor for SARS-CoV-2 in cells of the central nervous system (CNS), [60]. Since the onset of the COVID-19 pandemic, the emergence of new variants has been a global concern. However, association studies of clinical outcomes with SARS-CoV-2 variants have been scarce compared to the magnitude of the pandemic $[14,15]$. Some of them have reported preliminary results in small populations and there has been a lack of reproducibility in other clinical scenarios. Although statistically significant associations between outcomes and variants have been reported $[24,27,32,44]$, these are inconclusive and in some scenarios such associations have been opposing [50,51]. Likewise, it has been identified that not all variants impact disease development (Table 2).

Different clinical outcomes may be linked to genetic variations in SARS-CoV-2. However, it is necessary to adjust for the presence of individual risk factors in order to reliably establish such association (Table 2). In this context, most severe outcomes are associated with pre-existing diseases. Age and the presence of comorbidities such as hypertension, obesity, cardiovascular disease, immunosuppression, smoking, and diabetes mellitus are more important predictors of severity, hospitalization, and mortality than SARS-CoV-2 variants $[6,23,39,40,43,61,62]$. In the same way, the interaction of different SARS-CoV-2 variants with hosts is bidirectional. Different human polymorphisms have an impact on clinical outcomes: sequence changes in ApoE, TLR7, TMEM189-UBE2V1, as well as SLC6A20, LZTFL1, CCR9, FYCO1, CXCR6, XCR1, have been associated with severe disease outcomes as well as respiratory failure [12,63].

Notwithstanding the above, there are associated SARS-CoV-2 variant phenotypes that have significantly driven the course of the COVID-19 pandemic. This has been widely reported for COVs, in terms of transmissibility and potential evasion of neutralizing antibodies after vaccination or infections [7]. In this regard, the impact that new variants have on the reinfection of individuals has been documented, and some of them produce more severe disease than a first infection [64-68].

Several studies have been displaced as the pandemic progresses and new variants are reported, we have not yet been able to adapt our studies to such rapid changes according to the dynamics of the pandemic and the information that is generated every day, variants that could be considered of interest or have an impact on clinical outcomes, are quickly replaced by others that presented greater fitness [52]. Faced with such changes and the rapid emergence of variants, compared to our capacity to respond, we must seek approaches focused on anticipating future scenarios and not just reacting to established contexts. The Omicron variant (B.1.1.529), with more than 30 changes in the spike protein, as well as in other parts of its sequence, is an example of this; its accelerated infection rate in the world suggests a high capacity to reinfect people who have recovered from other variants such as Delta or to infect individuals with three-dose vaccinations, showing its capacity to evade immune responses and generate clinical outcomes different from those of other variants [69-71]. The course of the disease in patients infected with this variant, relative to previous waves, has been mild, with a significantly lower risk of hospitalization, severe disease, and ICU admission or death. However, it has not been clearly established whether this behavior is due to a lower pathogenicity of this variant or to pre-existing immunity [72-74].

As for the incubation period, it has been estimated that it may be shorter, around 2 to 3 days. The usual symptomatology is given by upper respiratory tract affection, which makes it difficult to differentiate from the common cold. [75-77]. It should be considered that although this variant does not present severe symptoms in a significant proportion of infected persons, the demand for care is high, such that detection and care capacity may be overwhelmed and primary care contact in health systems may collapse. The emergence of variants is an event that will continue to be repeated as time progresses. It has been proposed that in the face of new phases of the pandemic, coordinated approaches are required where global epidemiological surveillance and phenotypic characterization of new variants are linked [78]. However, this represents a challenge because in poor or emerging economy countries, variant sequencing may not be a priority, which coupled 
with low vaccination rates and lack of follow-up of sanitary measures, represents a potential risk for the emergence of new VOCs $[79,80]$.

As data on new SARS-CoV-2 variants become available, more associations can be established on their clinical outcome. However, these results need to be validated with other studies, in particular, those performed in vitro or in silico, and in observational studies where there was no adequate control of biases, which can lead to over-interpretation of results, affecting the degree of validity, reproducibility and reliability of these [81-83].

Regarding the critical appraisal of the analyzed articles, most of them were crosssectional and cohort studies, the sample size was heterogeneous, with a wide range, from 17 to 202,692 participants; their rating according to the Newcastle-Ottawa Quality Assessment Scale checklists was globally adequate (Table 3). Some studies were centered on small sample sizes, the lack of predictive models for disease progression, the use of a database to collect information without sampling specifications on factors of interest such as age, gender, ethnicity or population group, and without complete information on the clinical course or outcome of the disease, which in turn conditioned the presence of some selection and information biases, mainly in the sampling or in the available data to establish associations; in some studies, a low representation of SARS-CoV-2 variants was identified because the population was restricted to captive groups, as in the case of hospitalized patients.

\section{Limitations}

It has been pointed out that different clinical outcomes can be associated with the same variant and therefore, this places into context, the plasticity of virus-host interactions; thus, it is difficult to establish a univocal and generalized association between SARSCoV-2 variant and clinical outcomes $[33,44,47]$. Several models focused on measuring the association between disease severity and variant type have shown that once individual variables such as age, sex, ethnicity and comorbidity are neutralized, there is no significant difference in disease severity between variants. It has even been shown that they are not associated with increased hospital admissions, the latter being mostly associated with a higher viral load than with the infection variant itself $[6,43,62]$. Of the 15 articles that found statistically significant associations between SARS-CoV-2 variants and clinical outcomes, adjustments between various confounding variables were reported in only 8 of them (Table 2). For this reason, more studies are required to understand as a whole the influence of the different variables that impact on clinical outcomes [13,14].

The dynamics and fixation of new SARS-CoV-2 variants around the world has been rapid; several recently published studies focus on variants that have been displaced by other new ones, but that at the time were relevant for clinical outcomes [11], which shows that static scenarios for SARS-CoV-2 do not exist. Some of the information presented in this systematic review could become outdated in a short time; this has occurred in other diagnostic and therapeutic contexts due to the advances of the pandemic around the world and the accumulation of new knowledge related with COVID-19. [78,84-86].

This review highlights the impact of SARS-CoV-2 variants and clinical outcomes. Cross-sectional and cohort studies have undergone critical appraisal using an adapted appraisal tool; however, the rest of the studies were highlighted to their limitations, which should be viewed with caution. The analyzed articles were heterogeneous methodologically; some failed to mention potential confounding factors and to describe methods to control them (Tables 2 and 3). In this context, the analyzed studies make a quantitative analysis or meta-analysis unfeasible.

Some of the clinical outcomes presented in the reviewed articles did not conform to common outcome measures for the clinical follow-up of the disease [33,87]. It is important to adhere to these measures to identify clinical scenarios of relevance and to propose systematized responses to a pandemic that is far from over. It is recommended that authors who wish to establish associations between clinical outcomes and new variants be more 
exhaustive reporting these outcomes to cover various aspects associated with infections caused by SARS-CoV-2.

The limitations of this study were centered during the search period; the Omicron variant was announced by the WHO one day after the information was collected for this article; thus, its inclusion was not contemplated in this work. The search algorithm may have been biased in terms of specific searches for information related to clinical outcomes, since there may have been important outcomes that did not fit the algorithm and therefore were not included. Likewise, consulting two databases could have influenced the inclusion of new reports that could potentially increase our knowledge on the topic addressed in this systematic review.

\section{Conclusions}

The most identified SARS-CoV-2 variants in this study presented changes in the spike protein, N protein, RdRp, NSP3, as well as in different ORFs sequences. In most of the analyzed articles, possible associations between SARS-CoV-2 variants and clinical outcomes were found. However, only eight articles reported significant associations adjusting for age, sex, comorbidities, and other variables. There are multiple factors, such as age and preexisting diseases, involved in the course of COVID-19 disease, that have been determinant in the degree of severity. Nevertheless, the association between variants and clinical outcomes has not been fully explored at present; more research is required to establish possible associations between SARS-CoV-2 variants and illness behavior.

Author Contributions: Conceptualization, I.R.M.-P., E.L.-O. and G.L.-O.; articles review, I.R.M.-P., E.L.-O., J.G.R.d.1.L.-Z., J.G., A.G.-G. and G.L.-O.; writing-original draft preparation, I.R.M.-P., E.L.-O., J.G.R.d.1.L.-Z., J.G., A.G.-G. and G.L.-O.; writing-review and editing, J.G.R.d.1.L.-Z. and G.L.-O. All authors have read and agreed to the published version of the manuscript.

Funding: This research received no external funding.

Institutional Review Board Statement: Not applicable.

Informed Consent Statement: Not applicable.

Conflicts of Interest: The authors declare no conflict of interest.

\section{References}

1. Vijay, N.; Weissensteiner, M.; Burri, R.; Kawakami, T.; Ellegren, H.; Wolf, J.B.W. Genomewide patterns of variation in genetic diversity are shared among populations, species and higher-order taxa. Mol. Ecol. 2017, 26, 4284-4295. [CrossRef] [PubMed]

2. Franzo, G.; Drigo, M.; Legnardi, M.; Grassi, L.; Pasotto, D.; Menandro, M.; Cecchinato, M.; Tucciarone, C. Bovine Coronavirus: Variability, Evolution, and Dispersal Patterns of a No Longer Neglected Betacoronavirus. Viruses 2020, 12, 1285. [CrossRef] [PubMed]

3. Novel Swine-Origin Influenza A (H1N1) Virus Investigation Team. Emergence of a Novel Swine-Origin Influenza A (H1N1) Virus in Humans. N. Engl. J. Med. 2009, 360, 2605-2615. [CrossRef] [PubMed]

4. Torres, M.; de Mendonça, M.L.; Rodrigues, C.D.D.S.; Fonseca, V.; Ribeiro, M.; Brandão, A.; da Cunha, R.V.; Dias, A.; Boas, L.S.V.; Felix, A.; et al. Dengue Virus Serotype 2 Intrahost Diversity in Patients with Different Clinical Outcomes. Viruses 2021, 13, 349. [CrossRef] [PubMed]

5. Tsetsarkin, K.A.; VanLandingham, D.L.; McGee, C.E.; Higgs, S. A Single Mutation in Chikungunya Virus Affects Vector Specificity and Epidemic Potential. PLoS Pathog. 2007, 3, e201. [CrossRef] [PubMed]

6. Eaaswarkhanth, M.; Al Madhoun, A.; Al-Mulla, F. Could the D614G substitution in the SARS-CoV-2 spike (S) protein be associated with higher COVID-19 mortality? Int. J. Infect. Dis. 2020, 96, 459-460. [CrossRef]

7. Chadha, J.; Khullar, L.; Mittal, N. Facing the wrath of enigmatic mutations: A review on the emergence of severe acute respiratory syndrome coronavirus 2 variants amid coronavirus disease-19 pandemic. Environ. Microbiol. 2021. [CrossRef]

8. Mansbach, R.A.; Chakraborty, S.; Nguyen, K.; Montefiori, D.C.; Korber, B.; Gnanakaran, S. The SARS-CoV-2 Spike variant D614G favors an open conformational state. Sci. Adv. 2021, 7, eabf3671. [CrossRef]

9. Almubaid, Z.; Al-Mubaid, H. Analysis and comparison of genetic variants and mutations of the novel coronavirus SARS-CoV-2. Gene Rep. 2021, 23, 101064. [CrossRef]

10. Harvey, W.T.; Carabelli, A.M.; Jackson, B.; Gupta, R.K.; Thomson, E.C.; Harrison, E.M.; Ludden, C.; Reeve, R.; Rambaut, A.; COVID-19 Genomics UK (COG-UK) Consortium; et al. SARS-CoV-2 variants, spike mutations and immune escape. Nat. Rev. Microbiol. 2021, 19, 409-424. [CrossRef] 
11. Stirrup, O.; Boshier, F.; Venturini, C.; Guerra-Assunção, J.A.; Alcolea-Medina, A.; Beckett, A.; Charalampous, T.; Filipe, A.D.S.; Glaysher, S.; Khan, T.; et al. SARS-CoV-2 lineage B.1.1.7 is associated with greater disease severity among hospitalised women but not men: Multicentre cohort study. BMJ Open Respir. Res. 2021, 8, e001029. [CrossRef] [PubMed]

12. Anastassopoulou, C.; Gkizarioti, Z.; Patrinos, G.P.; Tsakris, A. Human genetic factors associated with susceptibility to SARS-CoV-2 infection and COVID-19 disease severity. Hum. Genom. 2020, 14, 1-8. [CrossRef] [PubMed]

13. Patone, M.; Thomas, K.; Hatch, R.; Tan, P.S.; Coupland, C.; Liao, W.; Mouncey, P.; Harrison, D.; Rowan, K.; Horby, P.; et al. Mortality and critical care unit admission associated with the SARS-CoV-2 lineage B.1.1.7 in England: An observational cohort study. Lancet Infect. Dis. 2021, 21, 1518-1528. [CrossRef]

14. Lin, L.; Liu, Y.; Tang, X.; He, D. The Disease Severity and Clinical Outcomes of the SARS-CoV-2 Variants of Concern. Front. Public Health 2021, 9, 775224. [CrossRef]

15. Courjon, J.; Contenti, J.; Demonchy, E.; Levraut, J.; Barbry, P.; Rios, G.; Dellamonica, J.; Chirio, D.; Bonnefoy, C.; Giordanengo, V.; et al. COVID-19 patients age, comorbidity profiles and clinical presentation related to the SARS-CoV-2 UK-variant spread in the Southeast of France. Sci. Rep. 2021, 11, 18456. [CrossRef]

16. Page, M.J.; McKenzie, J.E.; Bossuyt, P.M.; Boutron, I.; Hoffmann, T.C.; Mulrow, C.D.; Shamseer, L.; Tetzlaff, J.M.; Akl, E.A.; Brennan, S.E.; et al. The PRISMA 2020 statement: An updated guideline for reporting systematic reviews. BMJ 2021, 372, n71. [CrossRef]

17. Moola, S.; Munn, Z.; Sears, K.; Sfetcu, R.; Currie, M.; Lisy, K.; Tufanaru, C.; Qureshi, R.; Mattis, P.; Mu, P. Conducting systematic reviews of association (etiology). Int. J. Evid. Based Health 2015, 13, 163-169. [CrossRef] [PubMed]

18. Baharom, M.; Ahmad, N.; Hod, R.; Arsad, F.S.; Tangang, F. The Impact of Meteorological Factors on Communicable Disease Incidence and Its Projection: A Systematic Review. Int. J. Environ. Res. Public Health 2021, 18, 11117. [CrossRef]

19. Modesti, P.A.; Reboldi, G.; Cappuccio, F.P.; Agyemang, C.; Remuzzi, G.; Rapi, S.; Perruolo, E.; Parati, G. ESH Working Group on CV Risk in Low Resource Settings Panethnic Differences in Blood Pressure in Europe: A Systematic Review and Meta-Analysis. PLoS ONE 2016, 11, e0147601. [CrossRef]

20. Coding Manual for Cohort Studies. Available online: http://www.ohri.ca/programs/clinical_epidemiology/nos_manual.pdf/ (accessed on 17 December 2021).

21. Jin, X.; Lian, J.S.; Hu, J.H.; Gao, J.; Zheng, L.; Zhang, Y.M.; Hao, S.R.; Jia, H.Y.; Cai, H.; Zhang, X.L.; et al. Epidemiological, clinical and virological characteristics of 74 cases of coronavirus-infected disease 2019 (COVID-19) with gastrointestinal symptoms. Gut 2020, 69, 1002-1009. [CrossRef]

22. Mehta, P.; Alle, S.; Chaturvedi, A.; Swaminathan, A.; Saifi, S.; Maurya, R.; Chattopadhyay, P.; Devi, P.; Chauhan, R.; Kanakan, A.; et al. Clinico-Genomic Analysis Reveals Mutations Associated with COVID-19 Disease Severity: Possible Modulation by RNA Structure. Pathogens 2021, 10, 1109. [CrossRef] [PubMed]

23. Elizondo, V.; Harkins, G.W.; Mabvakure, B.; Smidt, S.; Zappile, P.; Marier, C.; Maurano, M.T.; Perez, V.; Mazza, N.; Beloso, C.; et al. SARS-CoV-2 genomic characterization and clinical manifestation of the COVID-19 outbreak in Uruguay. Emerg. Microbes Infect. 2021, 10, 51-65. [CrossRef] [PubMed]

24. Nagy, Á.; Pongor, S.; Győrffy, B. Different mutations in SARS-CoV-2 associate with severe and mild outcome. Int. J. Antimicrob. Agents 2021, 57, 106272. [CrossRef] [PubMed]

25. Isabel, S.; Graña-Miraglia, L.; Gutierrez, J.M.; Bundalovic-Torma, C.; Groves, H.E.; Isabel, M.R.; Eshaghi, A.; Patel, S.N.; Gubbay, J.B.; Poutanen, T.; et al. Evolutionary and structural analyses of SARS-CoV-2 D614G spike protein mutation now documented worldwide. Sci. Rep. 2020, 10, 14031. [CrossRef]

26. Müller, N.F.; Wagner, C.; Frazar, C.D.; Roychoudhury, P.; Lee, J.; Moncla, L.H.; Pelle, B.; Richardson, M.; Ryke, E.; Xie, H.; et al. Viral genomes reveal patterns of the SARS-CoV-2 outbreak in Washington State. Sci. Transl. Med. 2021, 13, eabf0202. [CrossRef]

27. Al Khatib, H.A.; Benslimane, F.M.; Elbashir, I.E.; Coyle, P.V.; Al Maslamani, M.A.; Al-Khal, A.; Al Thani, A.A.; Yassine, H.M. Within-Host Diversity of SARS-CoV-2 in COVID-19 Patients with Variable Disease Severities. Front. Cell. Infect. Microbiol. 2020, 10, 575613. [CrossRef]

28. Fournier, P.-E.; Colson, P.; Levasseur, A.; Devaux, C.A.; Gautret, P.; Bedotto, M.; Delerce, J.; Brechard, L.; Pinault, L.; Lagier, J.-C.; et al. Emergence and outcomes of the SARS-CoV-2 'Marseille-4' variant. Int. J. Infect. Dis. 2021, 106, 228-236. [CrossRef]

29. Hoang, V.-T.; Colson, P.; Levasseur, A.; Delerce, J.; Lagier, J.-C.; Parola, P.; Million, M.; Fournier, P.-E.; Raoult, D.; Gautret, P. Clinical outcomes in patients infected with different SARS-CoV-2 variants at one hospital during three phases of the COVID-19 epidemic in Marseille, France. Infect. Genet. Evol. 2021, 95, 105092. [CrossRef]

30. Morris, C.P.; Luo, C.H.; Amadi, A.; Schwartz, M.; Gallagher, N.; Ray, S.C.; Pekosz, A.; Mostafa, H.H. An Update on Severe Acute Respiratory Syndrome Coronavirus 2 Diversity in the US National Capital Region: Evolution of Novel and Variants of Concern. Clin. Infect. Dis. 2021, ciab636. [CrossRef]

31. Thomson, E.C.; Rosen, L.E.; Shepherd, J.G.; Spreafico, R.; Filipe, A.D.S.; Wojcechowskyj, J.A.; Davis, C.; Piccoli, L.; Pascall, D.J.; Dillen, J.; et al. Circulating SARS-CoV-2 spike N439K variants maintain fitness while evading antibody-mediated immunity. Cell 2021, 184, 1171-1187.e20. [CrossRef]

32. Fillâtre, P.; Dufour, M.-J.; Behillil, S.; Vatan, R.; Reusse, P.; Gabellec, A.; Velmans, N.; Montagne, C.; Du Coudret, S.G.; Droumaguet, E.; et al. A new SARS-CoV-2 variant with high lethality poorly detected by RT-PCR on nasopharyngeal samples: An observational study. Clin. Microbiol. Infect. 2021, 28, 298.e9-298.e15. [CrossRef] 
33. Gunadi; Wibawa, H.; Hakim, M.S.; Marcellus; Trisnawati, I.; El Khair, R.; Triasih, R.; Irene; Afiahayati; Iskandar, K.; et al. Molecular epidemiology of SARS-CoV-2 isolated from COVID-19 family clusters. BMC Med. Genom. 2021, 14, 144. [CrossRef] [PubMed]

34. Zhao, S.; Lou, J.; Chong, M.; Cao, L.; Zheng, H.; Chen, Z.; Chan, R.; Zee, B.; Chan, P.; Wang, M. Inferring the Association between the Risk of COVID-19 Case Fatality and N501Y Substitution in SARS-CoV-2. Viruses 2021, 13, 638. [CrossRef] [PubMed]

35. Nagy, Á.; Ligeti, B.; Szebeni, J.; Pongor, S.; Győrffy, B. COVIDOUTCOME—estimating COVID severity based on mutation signatures in the SARS-CoV-2 genome. Database 2021, 2021, baab020. [CrossRef] [PubMed]

36. Pang, X.; Li, P.; Zhang, L.; Que, L.; Dong, M.; Xie, B.; Wang, Q.; Wei, Y.; Xie, X.; Li, L.; et al. Emerging Severe Acute Respiratory Syndrome Coronavirus 2 Mutation Hotspots Associated with Clinical Outcomes and Transmission. Front. Microbiol. 2021, 12, 753823. [CrossRef] [PubMed]

37. Benton, D.J.; Wrobel, A.G.; Xu, P.; Roustan, C.; Martin, S.R.; Rosenthal, P.B.; Skehel, J.J.; Gamblin, S.J. Receptor binding and priming of the spike protein of SARS-CoV-2 for membrane fusion. Nature 2020, 588, 327-330. [CrossRef]

38. Benton, D.J.; Gamblin, S.J. SARS-CoV-2 Spike Glycoprotein with 2 ACE2 Bound. 2020. Available online: https://www.rcsb.org/ structure/7a97 (accessed on 19 January 2022).

39. Nakamichi, K.; Shen, J.Z.; Lee, C.S.; Lee, A.; Roberts, E.A.; Simonson, P.D.; Roychoudhury, P.; Andriesen, J.; Randhawa, A.K.; Mathias, P.C.; et al. Hospitalization and mortality associated with SARS-CoV-2 viral clades in COVID-19. Sci. Rep. 2021, 11, 1-11. [CrossRef]

40. Gunadi; Hakim, M.S.; Wibawa, H.; Marcellus; Trisnawati, I.; Supriyati, E.; Afiahayati; El Khair, R.; Iskandar, K.; Siswanto; et al. Association between prognostic factors and the outcomes of patients infected with SARS-CoV-2 harboring multiple spike protein mutations. Sci. Rep. 2021, 11, 21352. [CrossRef]

41. Cao, C.; He, L.; Tian, Y.; Qin, Y.; Sun, H.; Ding, W.; Gui, L.; Wu, P. Molecular epidemiology analysis of early variants of SARS-CoV-2 reveals the potential impact of mutations P504L and Y541C (NSP13) in the clinical COVID-19 outcomes. Infect. Genet. Evol. 2021, 92, 104831. [CrossRef]

42. Esper, F.P.; Cheng, Y.-W.; Adhikari, T.M.; Tu, Z.J.; Li, D.; Li, E.A.; Farkas, D.H.; Procop, G.W.; Ko, J.S.; Chan, T.A.; et al. Genomic Epidemiology of SARS-CoV-2 Infection During the Initial Pandemic Wave and Association with Disease Severity. JAMA Netw. Open 2021, 4, e217746. [CrossRef]

43. Siqueira, J.D.; Goes, L.R.; Alves, B.M.; de Carvalho, P.S.; Cicala, C.; Arthos, J.; Viola, J.P.B.; de Melo, A.C.; Soares, M. SARS-CoV-2 genomic analyses in cancer patients reveal elevated intrahost genetic diversity. Virus Evol. 2021, 7, veab013. [CrossRef]

44. Zekri, A.-R.N.; Mohanad, M.; Hafez, M.M.; Soliman, H.K.; Hassan, Z.K.; Abouelhoda, M.; Amer, K.E.; Seadawy, M.G.; Ahmed, O.S. Genome sequencing of SARS-CoV-2 in a cohort of Egyptian patients revealed mutation hotspots that are related to clinical outcomes. Biochim. Biophys. Acta 2021, 1867, 166154. [CrossRef] [PubMed]

45. de Sousa, E.; Ligeiro, D.; Lérias, J.R.; Zhang, C.; Agrati, C.; Osman, M.; El-Kafrawy, S.A.; Azhar, E.I.; Ippolito, G.; Wang, F.-S.; et al Mortality in COVID-19 disease patients: Correlating the association of major histocompatibility complex (MHC) with severe acute respiratory syndrome 2 (SARS-CoV-2) variants. Int. J. Infect. Dis. 2020, 98, 454-459. [CrossRef] [PubMed]

46. Young, B.E.; Wei, W.E.; Fong, S.-W.; Mak, T.-M.; Anderson, D.E.; Chan, Y.-H.; Pung, R.; Heng, C.S.; Ang, L.W.; Zheng, A.K.E.; et al. Association of SARS-CoV-2 clades with clinical, inflammatory and virologic outcomes: An observational study. EBioMedicine 2021, 66, 103319. [CrossRef] [PubMed]

47. Li, Z.; Li, Y.; Sun, R.; Li, S.; Chen, L.; Zhan, Y.; Xie, M.; Yang, J.; Wang, Y.; Zhu, A.; et al. Longitudinal virological changes and underlying pathogenesis in hospitalized COVID-19 patients in Guangzhou, China. Sci. China Life Sci. 2021, 64, 2129-2143. [CrossRef]

48. Dao, T.L.; Hoang, V.T.; Nguyen, N.N.; Delerce, J.; Chaudet, H.; Levasseur, A.; Lagier, J.C.; Raoult, D.; Colson, P.; Gautret, P. Clinical outcomes in COVID-19 patients infected with different SARS-CoV-2 variants in Marseille, France. Clin. Microbiol. Infect. 2021, 27, 1516.e1-1516.e6. [CrossRef]

49. Veneti, L.; Seppälä, E.; Storm, M.L.; Salamanca, B.V.; Buanes, E.A.; Aasand, N.; Naseer, U.; Bragstad, K.; Hungnes, O.; Bøås, H.; et al. Increased Risk of Hospitalisation and Intensive Care Admission Associated with Reported Cases of SARS-CoV-2 Variants B.1.1.7 and B.1.351 in Norway, December 2020-May 2021. PLoS ONE 2021, 16, e0258513. [CrossRef]

50. Ong, S.W.X.; Chiew, C.J.; Ang, L.W.; Mak, T.-M.; Cui, L.; Toh, M.P.H.; Lim, Y.D.; Lee, P.H.; Lee, T.H.; Chia, P.Y.; et al. Clinical and Virological Features of SARS-CoV-2 Variants of Concern: A Retrospective Cohort Study Comparing B.1.1.7 (Alpha), B.1.315 (Beta), and B.1.617.2 (Delta). SSRN J. 2021, ciab721. [CrossRef]

51. Taylor, C.A.; Patel, K.; Pham, H.; Whitaker, M.; Anglin, O.; Kambhampati, A.K.; Milucky, J.; Chai, S.J.; Kirley, P.D.; Alden, N.B.; et al. Severity of Disease Among Adults Hospitalized with Laboratory-Confirmed COVID-19 Before and During the Period of SARS-CoV-2 B.1.617.2 (Delta) Predominance-COVID-NET, 14 States, January-August 2021. MMWR Morb. Mortal. Wkly. Rep. 2021, 70, 1513-1519. [CrossRef]

52. Bian, L.; Gao, F.; Zhang, J.; He, Q.; Mao, Q.; Xu, M.; Liang, Z. Effects of SARS-CoV-2 variants on vaccine efficacy and response strategies. Expert Rev. Vaccines 2021, 20,365-373. [CrossRef]

53. Rochman, N.D.; Wolf, Y.I.; Faure, G.; Mutz, P.; Zhang, F.; Koonin, E.V. Ongoing global and regional adaptive evolution of SARS-CoV-2. Proc. Natl. Acad. Sci. USA 2021, 118, 2104241118. [CrossRef] [PubMed]

54. Zhang, Q.; Xiang, R.; Huo, S.; Zhou, Y.; Jiang, S.; Wang, Q.; Yu, F. Molecular mechanism of interaction between SARS-CoV-2 and host cells and interventional therapy. Signal. Transduct. Target. Ther. 2021, 6, 233. [CrossRef] [PubMed] 
55. Komiyama, M. Molecular-level Anatomy of SARS-CoV-2 for the Battle against COVID-19 Pandemic. Bull. Chem. Soc. Jpn. 2021, 94, 1478-1490. [CrossRef]

56. Korber, B.; Fischer, W.M.; Gnanakaran, S.; Yoon, H.; Theiler, J.; Abfalterer, W.; Hengartner, N.; Giorgi, E.E.; Bhattacharya, T.; Foley, B.; et al. Tracking Changes in SARS-CoV-2 Spike: Evidence that D614G Increases Infectivity of the COVID-19 Virus. Cell 2020, 182, 812-827.e19. [CrossRef]

57. Yurkovetskiy, L.; Wang, X.; Pascal, K.E.; Tomkins-Tinch, C.; Nyalile, T.P.; Wang, Y.; Baum, A.; Diehl, W.E.; Dauphin, A.; Carbone, C.; et al. Structural and Functional Analysis of the D614G SARS-CoV-2 Spike Protein Variant. Cell 2020, 183, 739-751.e8. [CrossRef]

58. Plante, J.A.; Liu, Y.; Liu, J.; Xia, H.; Johnson, B.A.; Lokugamage, K.G.; Zhang, X.; Muruato, A.E.; Zou, J.; Fontes-Garfias, C.R.; et al. Spike mutation D614G alters SARS-CoV-2 fitness. Nature 2021, 592, 116-121. [CrossRef] [PubMed]

59. Lubinski, B.; Fernandes, M.H.; Frazier, L.; Tang, T.; Daniel, S.; Diel, D.G.; Jaimes, J.A.; Whittaker, G.R. Functional evaluation of the P681H mutation on the proteolytic activation of the SARS-CoV-2 variant B.1.1.7 (Alpha) spike. iScience 2021, 25, 103589. [CrossRef]

60. Chakravarty, N.; Senthilnathan, T.; Paiola, S.; Gyani, P.; Cario, S.C.; Urena, E.; Jeysankar, A.; Jeysankar, P.; Irudayam, J.I.; Subramanian, S.N.; et al. Neurological pathophysiology of SARS-CoV-2 and pandemic potential RNA viruses: A comparative analysis. FEBS Lett. 2021, 595, 2854-2871. [CrossRef]

61. Van Der Made, C.I.; Simons, A.; Schuurs-Hoeijmakers, J.; Heuvel, G.V.D.; Mantere, T.; Kersten, S.; Van Deuren, R.C.; Steehouwer M.; Van Reijmersdal, S.V.; Jaeger, M.; et al. Presence of Genetic Variants Among Young Men with Severe COVID-19. JAMA 2020, 324, 663. [CrossRef]

62. Akkiz, H. Implications of the Novel Mutations in the SARS-CoV-2 Genome for Transmission, Disease Severity, and the Vaccine Development. Front. Med. 2021, 8, 636532. [CrossRef]

63. Severe Covid-19 GWAS Group. Genomewide Association Study of Severe Covid-19 with Respiratory Failure. N. Engl. J. Med. 2020, 383, 1522-1534. [CrossRef] [PubMed]

64. Jeffery-Smith, A.; Rowland, T.A.J.; Patel, M.; Whitaker, H.; Iyanger, N.; Williams, S.V.; Giddings, R.; Thompson, L.; Zavala, M.; Aiano, F; et al. Reinfection with new variants of SARS-CoV-2 after natural infection: A prospective observational cohort in 13 care homes in England. Lancet Health Longev. 2021, 2, e811-e819. [CrossRef]

65. Shastri, J.; Parikh, S.; Aggarwal, V.; Agrawal, S.; Chatterjee, N.; Shah, R.; Devi, P.; Mehta, P.; Pandey, R. Severe SARS-CoV-2 Breakthrough Reinfection with Delta Variant After Recovery from Breakthrough Infection by Alpha Variant in a Fully Vaccinated Health Worker. Front. Med. 2021, 8, 737007. [CrossRef]

66. Fakhroo, A.; AlKhatib, H.A.; Al Thani, A.A.; Yassine, H.M. Reinfections in COVID-19 Patients: Impact of Virus Genetic Variability and Host Immunity. Vaccines 2021, 9, 1168. [CrossRef] [PubMed]

67. Garduño-Orbe, B.; Sánchez-Rebolledo, J.; Cortés-Rafael, M.; García-Jiménez, Y.; Perez-Ortiz, M.; Mendiola-Pastrana, I.; LópezOrtiz, E.; López-Ortiz, G. SARS-CoV-2 Reinfection among Healthcare Workers in Mexico: Case Report and Literature Review. Medicina 2021, 57, 442. [CrossRef] [PubMed]

68. Muzio, L.L.; Ambosino, M.; Muzio, E.L.; Quadri, M.F.A. SARS-CoV-2 Reinfection Is a New Challenge for the Effectiveness of Global Vaccination Campaign: A Systematic Review of Cases Reported in Literature. Int. J. Environ. Res. Public Health 2021, 18, 11001. [CrossRef]

69. Callaway, E.; Ledford, H. How bad is Omicron? What scientists know so far. Nature 2021, 600, 197-199. [CrossRef]

70. Gao, S.-J.; Guo, H.; Luo, G. Omicron variant (B.1.1.529) of SARS-CoV-2, a global urgent public health alert! J. Med. Virol. 2021, jmv.27491. [CrossRef]

71. Karim, S.S.A.; Karim, Q.A. Omicron SARS-CoV-2 variant: A new chapter in the COVID-19 pandemic. Lancet 2021, 398, $2126-2128$. [CrossRef]

72. Cele, S.; Jackson, L.; Khoury, D.S.; Khan, K.; Moyo-Gwete, T.; Tegally, H.; San, J.E.; Cromer, D.; Scheepers, C.; Amoako, D.G.; et al. Omicron extensively but incompletely escapes Pfizer BNT162b2 neutralization. Nature 2021, 1-5. [CrossRef]

73. Singhal, T. The Emergence of Omicron: Challenging Times Are Here Again! Indian J. Pediatr. 2022, 13, 1-7. [CrossRef] [PubMed]

74. Ferguson, N.; Ghani, A.; Hinsley, W.; Volz, E. Hospitalisation Risk for Omicron Cases in England; Imperial College London: London, UK, 2021. [CrossRef]

75. Jansen, L.; Tegomoh, B.; Lange, K.; Showalter, K.; Figliomeni, J.; Abdalhamid, B.; Iwen, P.C.; Fauver, J.; Buss, B.; Donahue, M. Investigation of a SARS-CoV-2 B.1.1.529 (Omicron) Variant Cluster-Nebraska, November-December 2021. MMWR. Morb. Mortal. Wkly. Rep. 2021, 70, 1782-1784. [CrossRef] [PubMed]

76. Wolter, N.; Jassat, W.; Walaza, S.; Welch, R.; Moultrie, H.; Groome, M.; Amoako, D.G.; Everatt, J.; Bhiman, J.N.; Scheepers, C.; et al. Early Assessment of the Clinical Severity of the SARS-CoV-2 Omicron Variant in South Africa. medRxiv 2021. preprint. [CrossRef]

77. Maslo, C.; Friedland, R.; Toubkin, M.; Laubscher, A.; Akaloo, T.; Kama, B. Characteristics and Outcomes of Hospitalized Patients in South Africa During the COVID-19 Omicron Wave Compared with Previous Waves. JAMA 2021. [CrossRef] [PubMed]

78. Munnink, B.B.O.; Worp, N.; Nieuwenhuijse, D.F.; Sikkema, R.S.; Haagmans, B.; Fouchier, R.A.M.; Koopmans, M. The next phase of SARS-CoV-2 surveillance: Real-time molecular epidemiology. Nat. Med. 2021, 27, 1518-1524. [CrossRef]

79. Chackalackal, D.J.; Al-Aghbari, A.A.; Jang, S.Y.; Ramirez, T.R.; Vincent, J.; Joshi, A.; Banjara, M.R.; Asaga, P.; Sanchez, R.C.; Carrillo, M.A.; et al. The Covid-19 pandemic in low- and middle-income countries, who carries the burden? Review of mass media and publications from six countries. Pathog. Glob. Health 2021, 115, 178-187. [CrossRef] 
80. Hasan, M.M.; Rocha, I.C.N.; Ramos, K.G.; Cedeño, T.D.D.; Costa, A.C.D.S.; Tsagkaris, C.; Billah, M.; Ahmad, S.; Essar, M.Y. Emergence of highly infectious SARS-CoV-2 variants in Bangladesh: The need for systematic genetic surveillance as a public health strategy. Trop. Med. Health 2021, 49, 69. [CrossRef]

81. Anderson, C.; Nugent, K.; Peterson, C. Academic Journal Retractions and the COVID-19 Pandemic. J. Prim. Care Community Health 2021, 12, 215013272110155. [CrossRef]

82. Ioannidis, J.P.A. Why Most Published Research Findings Are False. PLoS Med. 2005, 2, e124. [CrossRef]

83. Cortegiani, A.; Catalisano, G.; Ippolito, M.; Giarratano, A.; Absalom, A.R.; Einav, S. Retracted papers on SARS-CoV-2 and COVID-19. Br. J. Anaesth. 2021, 126, e155-e156. [CrossRef]

84. Heidary, F.; Gharebaghi, R. Ivermectin: A systematic review from antiviral effects to COVID-19 complementary regimen. J. Antibiot. 2020, 73, 593-602. [CrossRef] [PubMed]

85. Pastrana, I.R.M.; Ortiz, E.L.; González, J.; Torres, I.H.; Mendoza, M.F.; Flores, W.V.; Lastra, E.R.; Ortiz, G.L. SARS-CoV-2: Desde sus aspectos genómicos y estructurales hasta su tratamiento. Atención Fam. 2020, 27, 3-12. [CrossRef]

86. Cortegiani, A.; Ingoglia, G.; Ippolito, M.; Giarratano, A.; Einav, S. A systematic review on the efficacy and safety of chloroquine for the treatment of COVID-19. J. Crit. Care 2020, 57, 279-283. [CrossRef] [PubMed]

87. Marshall, J.C.; Murthy, S.; Diaz, J.; Adhikari, N.K.; Angus, D.C.; Arabi, Y.M.; Baillie, K.; Bauer, M.; Berry, S.; Blackwood, B.; et al. A Minimal Common Outcome Measure Set for COVID-19 Clinical Research. Lancet Infect. Dis. 2020, 20, e192-e197. [CrossRef] 